\title{
Ionic liquids as novel media for electrophilic/onium ion chemistry and metal-mediated reactions: a progress summary
}

\author{
Kenneth K. Laali \\ Department of Chemistry, University of North Florida \\ 1 UNF Drive, Jacksonville, Florida 32224, USA \\ E-mail: Kenneth.Laali@,UNF.edu
}

DOI: $\underline{\text { http://dx.doi.org/10.3998/ark.5550190.p009.490 }}$

\begin{abstract}
The account presented here summarizes progress from the author's laboratory during the past 15 years on the application of room temperature ionic liquids (RTILs) as solvents and catalysts in electrophilic/onium ion chemistry as well as in metal-mediated bond forming reactions.
\end{abstract}

Keywords: Ionic liquids; nitration; halogenation; heterocyclic synthesis; catalysis; propargylation; Heck coupling

\section{Table of Contents}

1. Introduction

2. Nitration

3. Aromatic Benzylation

4. Adamantylation of Aromatics

5. Transacylation and Deacylation

6. Organofluorine Chemistry

6.1 Fluorodediazoniation

6.2 Aromatic Fluorination with Selectfluor (F-TEDA-BF 4 )

$6.3 \alpha$-Fluorination of Carbonyl Compounds

7. Synthesis of High Value Small Molecules by Dediazoniative Functionalization

7.1 Halo- and Azido-dediazoniation in ILs

7.2 Dediazoniation in [BMIM] $\left.\mathrm{NTf}_{2}\right]$

8. Aromatic Halogenation

8.1 Chlorination of Arenes with Trichloroisocyanuric acid (TCICA)

8.2 Halofunctionalization with $\mathrm{I}_{2} / \mathrm{H}_{2} \mathrm{O}_{2}$ and with N-Halosuccinimides (NXS)

8.3 Metal and $\mathrm{H}_{2} \mathrm{O}_{2}$ Free Aerobic Oxidative Aromatic Halogenation

9. Catalysis by Metallic Triflates and Brønsted Acidic IL 


\subsection{The Ritter Reaction}

9.2 The Schmidt Reaction of Aldehydes

9.3 Rearrangement of 1,2-Diaryl Epoxides

9.4 Building Heterocyclic Systems

10. Tetrazoles and Tetrazolium-Based ILs

11. Development of Facile Propargylation Methods in ILs

11.1 Propargylated Arenes, Heteroarenes, and Ethers

11.2 Propargylation of 1,3-Dicarbonyl Compounds and 4-Hydroxycoumarin

11.3 Propargylation of Indoles and Carbazole

11.4 Coupling of Allyl- and Alkynylsilanes with Propargylic, Allylic, and Benzylic Alcohols

11.5 Metal-Free Rupe Rearrangement in ILs

12. Metal-Mediated Cross-Coupling Reactions and Cyclizations in IL

13. Summary

Acknowledgements

References

\section{Introduction}

Application of ionic liquids (ILs) in synthetic chemistry and catalysis has been growing steadily over the past two decades and the trajectory continues to remain positive. The progress in this evolving and dynamic area has been summarized over the years in a number of reviews, commentaries, and highlights. ${ }^{1-25}$

Having worked for many years in carbocation and onium ion chemistry, starting in 1999 we began tinkering with room temperature ionic liquids (RTILs) bearing low nucleophilicity counter ions $\left(\mathrm{OTf}, \mathrm{PF}_{6}, \mathrm{BF}_{4}\right.$, and $\mathrm{NTf}_{2}$ ). We were intrigued by the idea that the cationic core in $[\mathrm{BMIM}][\mathrm{X}]$ and [EMIM][X] imidazolium ILs (Figure 1) may be sufficiently Lewis-acidic for the IL to act not only as solvent but also as catalyst, and that the Lewis acidity of the cationic core could be increased by introducing electron withdrawing group(s), or by employing less nucleophilic counter ions. We envisaged that through these structural changes ILs could be tailor-made for a variety of acid-catalyzed reactions. Ease of product isolation/work-up, recycling and reuse of the ILs provided additional impetus. We later learned that various onium salts could be made to dissolve in imidazolium ILs such as [BMIM] $\left[\mathrm{PF}_{6}\right]$ and $[\mathrm{BMIM}]\left[\mathrm{BF}_{4}\right]$ with the help of sonication, and this motivated us to focus on developing or improving on synthetic methods that utilize onium salts as reagent, and by doing so increase the synthetic value of onium salts for method development. An important objective was to develop newer, environmentally more acceptable, synthetic methods for fundamentally important/textbook transformations, especially those that are practiced on large scale in industry such as nitration and halogenation. Combinations of [BMIM] $[\mathrm{X}]$ ILs as solvent and metallic triflates $\mathrm{M}(\mathrm{OTf})_{3}$, or Brønsted acidic ILs $\left[\mathrm{BMIM}\left(\mathrm{SO}_{3} \mathrm{H}\right)\right][\mathrm{OTf}]$ or $\left[\mathrm{PMIM}\left(\mathrm{SO}_{3} \mathrm{H}\right)\right][\mathrm{OTf}]$ as catalyst (Figure 1) proved 
rewarding in a variety of acid-catalyzed carbocationic transformations, as well as in heterocyclic synthesis, and in organofluorine chemistry. Imidazolium ILs also proved quite useful as solvent in Pd-catalyzed C-C coupling reactions. The present account summarizes these studies.
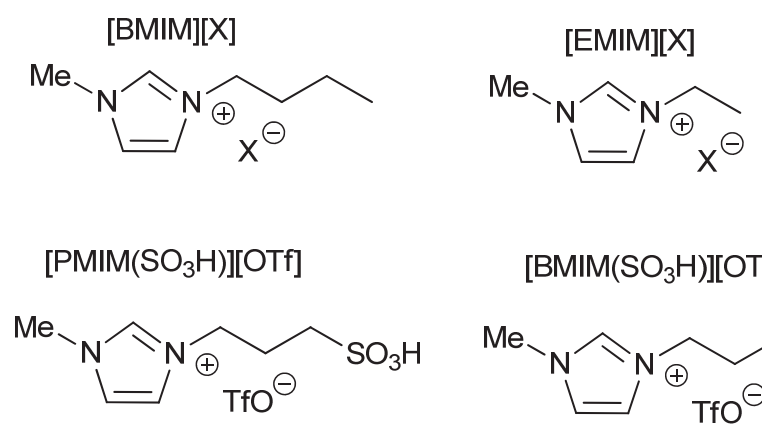

$$
\left[\mathrm{BMIM}\left(\mathrm{SO}_{3} \mathrm{H}\right)\right][\mathrm{OTf}]
$$

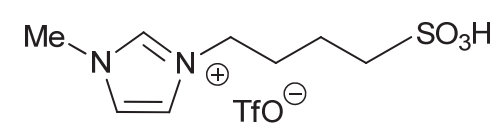

Figure 1. Imidazolium ILs as alternative solvents and catalysts.

\section{Nitration}

One of the earliest studies we made was to determine the scope of aromatic nitration in imidazolium ILs. ${ }^{26}$ The most promising systems identified in a survey study with simple arenes were isoamyl nitrate/TfOH, isoamyl nitrate $/ \mathrm{BF}_{3} . \mathrm{Et}_{2} \mathrm{O}$, and $\mathrm{NH}_{4} \mathrm{NO}_{3} / \mathrm{TFAA}$, as well as $\mathrm{AgNO}_{3} / \mathrm{Tf}_{2} \mathrm{O}$ (Scheme 1). In most cases the yields and isomer distributions (ortho/para ratios) for nitration in ILs were comparable to those employing conventional methods, suggesting similarity in the mechanism.

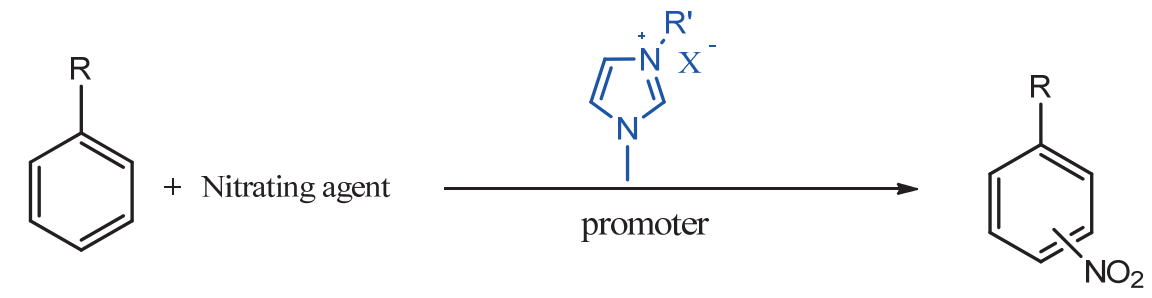

$$
\begin{aligned}
& \text { Nitrating agent: } \mathrm{NO}_{2} \mathrm{BF}_{4} ; \text { isoamylnitrate; } \mathrm{NH}_{4} \mathrm{NO}_{3} ; \mathrm{AgNO}_{3} \\
& \text { Promoter: TFAA; TfOH; } \mathrm{Tf}_{2} \mathrm{O} ; \mathrm{BF}_{3} \cdot \mathrm{Et}_{2} \mathrm{O} \\
& \mathrm{R}=\mathrm{H}, \mathrm{OMe} ; 1-\mathrm{OMe} / 4-\mathrm{Me} ; \mathrm{tBu} ; 1,3,5-\text { tri-Me; } \mathrm{F} ; \mathrm{Me} ; 4-\mathrm{F} / 1-\mathrm{Me} ; \mathrm{CF}_{3} ; \mathrm{Ar}=\text { napthalene } \\
& \mathrm{X}=\mathrm{Cl}, \mathrm{CF}_{3} \mathrm{COO}, \mathrm{OTf}, \mathrm{NO}_{3}, \mathrm{BF}_{4} ; \mathrm{PF}_{6} \\
& \mathrm{R}^{\prime}=\mathrm{Et} ; \mathrm{n}-\mathrm{Bu}
\end{aligned}
$$

Scheme 1. Nitration of arenes in imidazolium ILs.

In a later study we employed ethylammonium nitrate (EAN) as a cheap and easily accessible IL. EAN in combination with TFAA or $\mathrm{Tf}_{2} \mathrm{O}$ acts as an in-situ source of trifluoroacetyl nitrate $\left(\mathrm{CF}_{3} \mathrm{COONO}_{2}\right)$ and triflyl nitrate $\left(\mathrm{TfONO}_{2}\right)$ respectively (Scheme 2). ${ }^{27}$ These systems proved quite effective for nitration of a wide variety of aromatic and 
heteroaromatic compounds, with $\mathrm{EAN} / \mathrm{Tf}_{2} \mathrm{O}$ being superior for nitration of deactivated compounds.

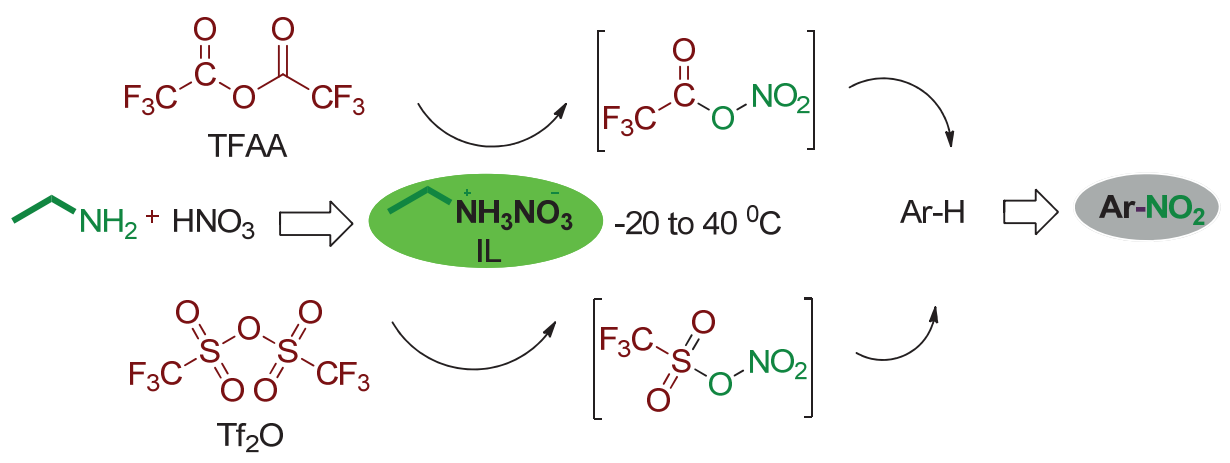

Scheme 2. EAN/TFAA and $\mathrm{EAN} / \mathrm{Tf}_{2} \mathrm{O}$ systems for aromatic nitration.

In another study we examined the utility and scope of arene nitration with bismuth nitrate $(\mathrm{BN})$ in IL solvent. ${ }^{28}$ (Scheme 3) The $\mathrm{BN} /[\mathrm{BMIM}]\left[\mathrm{PF}_{6}\right]$ combination proved efficient for nitration of activated arenes under mild conditions without the need for external promoters. Reactions were faster in the IL solvent as compared to those in 1,2-dichloroethane (DCE), but $\mathrm{BN} / \mathrm{DCE}$ proved more effective for nitration of deactivated aromatics.

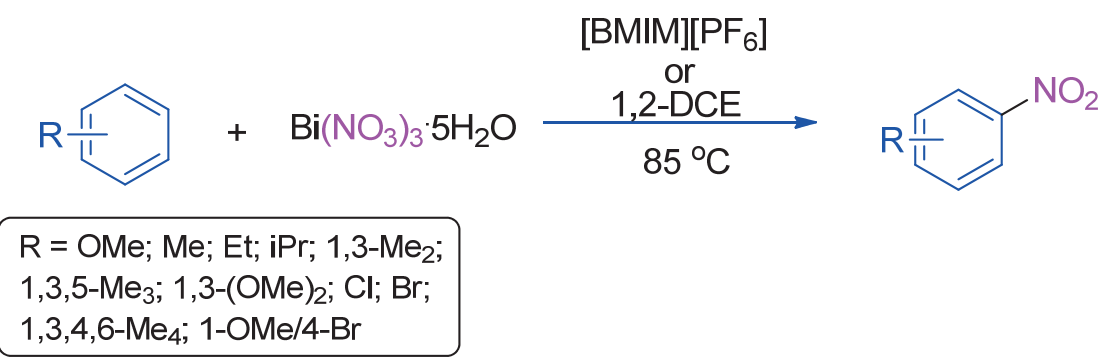

Scheme 3. Nitration of arenes with BN/IL and comparison with BN/DCE.

\section{Aromatic Benzylation}

Aromatic benzylation is a widely practiced fundamental transformation for the preparation of diarylmethanes which are important synthetic intermediates. Benzylation of arenes with $\mathrm{PhCH}_{2} \mathrm{Cl}$ and $\mathrm{PhCH}_{2} \mathrm{OH}$ were conveniently performed in [BMIM] [OTf] or [BMIM] $\left[\mathrm{PF}_{6}\right]$ by using $\mathrm{TfOH}, \mathrm{Sc}(\mathrm{OTf})_{3}$, or $\mathrm{Yb}(\mathrm{OTf})_{3} \cdot \mathrm{xH}_{2} \mathrm{O}$ as catalysts (Scheme 4). ${ }^{29 \mathrm{a}} \mathrm{TfOH}$ was superior for benzylation with $\mathrm{BzOH}$, producing little or no dibenzyl ether (DBE). Substrate selectivity $\left(K_{\mathrm{T}} / K_{\mathrm{b}}\right)$ and regioselectivity (isomer distribution) for benzylation in the IL solvents employing $\mathrm{TfOH}$ or $\mathrm{Yb}(\mathrm{OTf})_{3}$ were in similar range to those reported in molecular solvents employing 
Nafion-H. ${ }^{29 b}$ The advantages offered by this method are high yields and chemoselectivity (absence of DBE), easy isolation, and recycling/reuse of the IL.

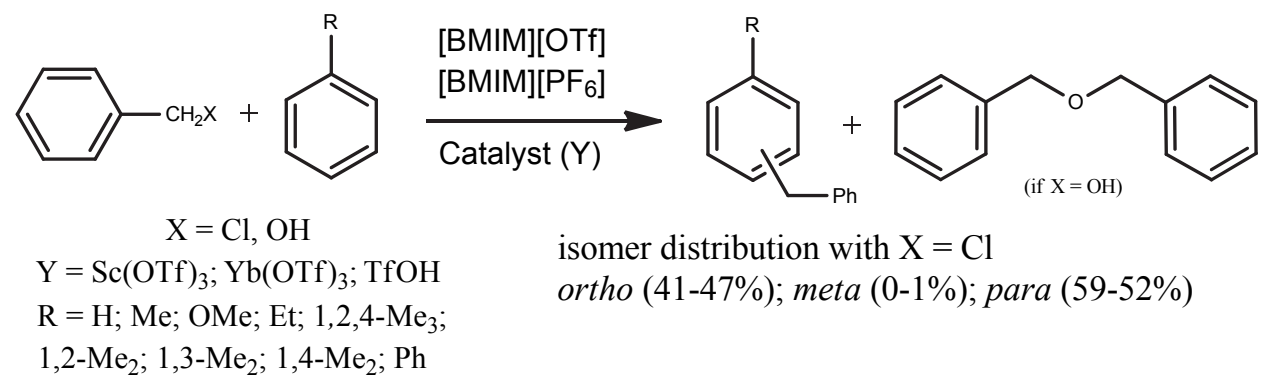

Scheme 4. Benzylation of arenes in ILs.

\section{Adamantylation of Aromatics}

The system [BMIM][OTf]-TfOH proved highly efficient for adamantylation of arenes with 1AdaX (X $=\mathrm{OH}, \mathrm{Cl}, \mathrm{Br}$ ) (Scheme 5). ${ }^{30}$ The reactions exhibited high para selectivity, produced little or no adamantane byproduct, and the conversions were quantitative or near quantitative.

The synthetic scope of the reaction was investigated and competitive reactions were carried out to shed light on the mechanistic issues, in particular the origin of high meta in TfOH-catalyzed adamantylation of toluene in DCE as solvent. Notable differences in substrate selectivity $\left(K_{\mathrm{t}} / K_{\mathrm{b}}\right.$ values were in the range 16-17 in the ionic liquid solvent and close to unity in DCE), and chemo-, and regioselectivity were observed in [BMIM][OTf] versus DCE. ${ }^{30}$ The data implied a comparatively later (more benzenium ion like) TS in the IL solvent, involving a more selective electrophile.

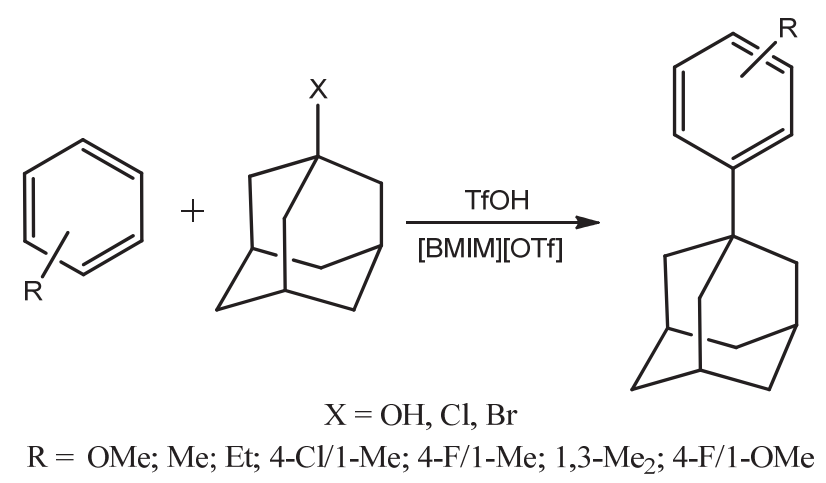

Scheme 5. Adamantylation of arenes in IL solvent. 


\section{Transacylation and Deacylation}

Sterically hindered acetophenones undergo acyl group transfer to reactive aromatic nucleophile receptors (anisole, toluene) in imidazolium ILs as solvent with $\mathrm{TfOH}$ as promoter (Scheme 6). These superacid promoted reactions likely involve a deacetylation/reacetylation process. Chemoselectivity (transacylation versus deacylation) depends on the reaction temperature. High conversions could be achieved by tweaking the reaction conditions namely the arene/TfOH ratio, choice of arene receptor, and the reaction time. ${ }^{31}$

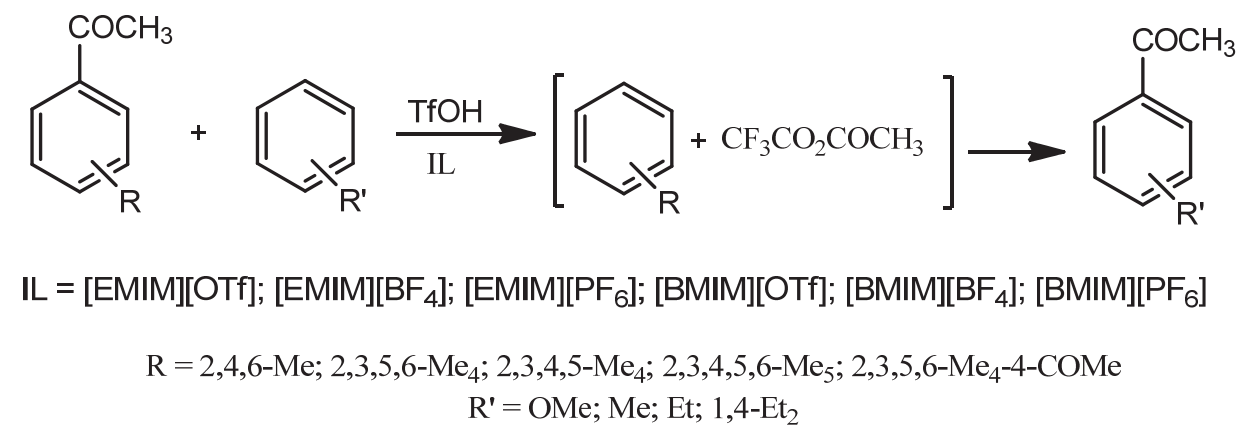

Scheme 6. Transacylation and deacylation

\section{Organofluorine Chemistry}

\subsection{Fluorodediazoniation}

The finding that arenediazonium salts could be made to dissolve in imidazolium ILs provided the motivation to develop a new method for the classical Balz-Schiemann reaction. ${ }^{32}$ The classical procedure suffered from drawbacks with regard to reproducibility and variable yields depending on the choice of the arene. The arenediazonium tetrafluoroborates were allowed to dediazoniate in $[\mathrm{BMIM}]\left[\mathrm{BF}_{4}\right]$ or $[\mathrm{BMIM}]\left[\mathrm{PF}_{6}\right]$ to cleanly furnish the corresponding fluoroaromatic compounds essentially in quantitative yields. The reaction could also be carried out in one-pot starting from the anilines by in-situ diazotization with nitrosonium salts (Scheme 7).

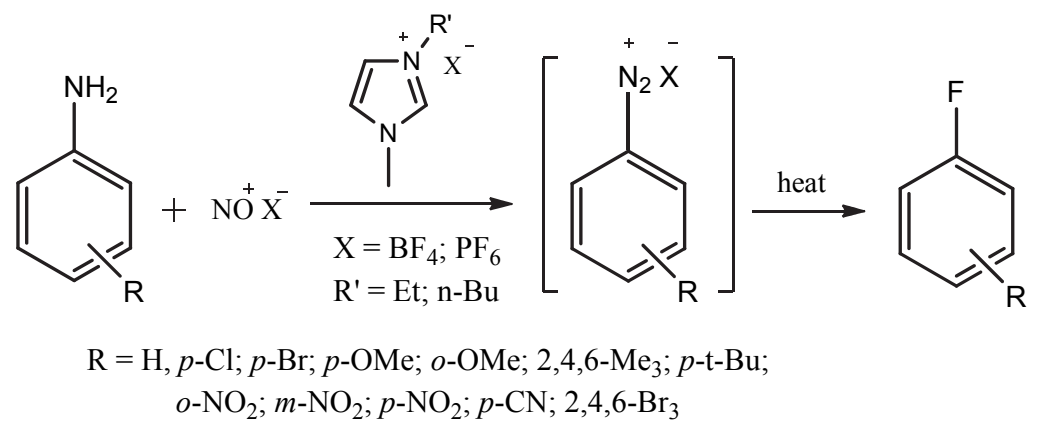

Scheme 7. Diazotization-fluorodediazoniation in ILs. 


\subsection{Aromatic Fluorination with Selectfluor (F-TEDA-BF 4 )}

As an onium dication salt Selectfluor dissolves in excess imidazolium ILs and this "immobilization" process is aided by sonication, providing a convenient medium for arene fluorination (Scheme 8). By using this approach the scope of arene fluorination was investigated, and the corresponding fluoro derivatives were obtained under mild conditions in reasonable yields as determine by NMR and GC. ${ }^{33}$ The study was subsequently extended to fluorination of bicyclic and polycyclic arenes. The substrate selectivity measured in competitive reaction $\left(K_{\text {mesitylene }}: K_{\text {durene }}=10\right)$ is in line with a conventional polar mechanism. ${ }^{33}$

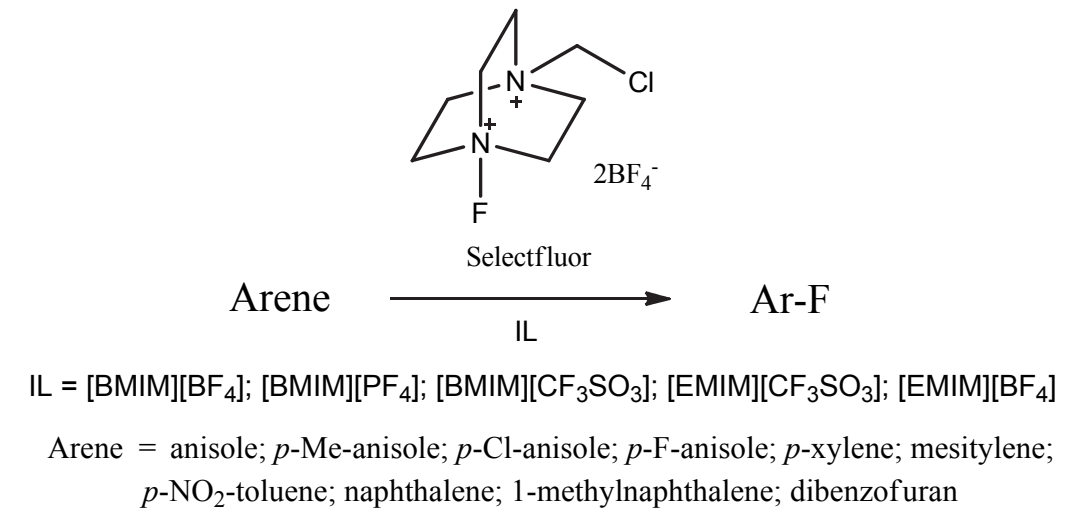

Scheme 8. Arene fluorination with Selectfluor in imidazolium-ILs.

\section{3 a-Fluorination of Carbonyl Compounds}

By employing a combination of two imidazolium ILs, namely [BMIM][PF 6$]$ or [BMIM][NTf $\left.\mathrm{B}_{2}\right]$ acting as solvent (IL-1) and a Brønsted-acidic imidazolium salt [PMIM( $\left.\left(\mathrm{SO}_{3} \mathrm{H}\right)\right][\mathrm{OTf}]$ acting as promoter (IL-2), structurally diverse ketones, 1,3-diketones, and $\beta$-ketoesters were selectively monofluorinated with Selectfluor (Scheme 9). ${ }^{34}$ Further fluorination to the gem-difluoro derivatives was effected by addition of another equivalent of Selectfluor. Direct gemdifluorination could be achieved starting from the corresponding carbonyl compounds by using two equivalents of Selectfluor. This synthetic method was also applicable to $\alpha$-monofluorination of $\alpha$-nitroketones. ${ }^{34}$

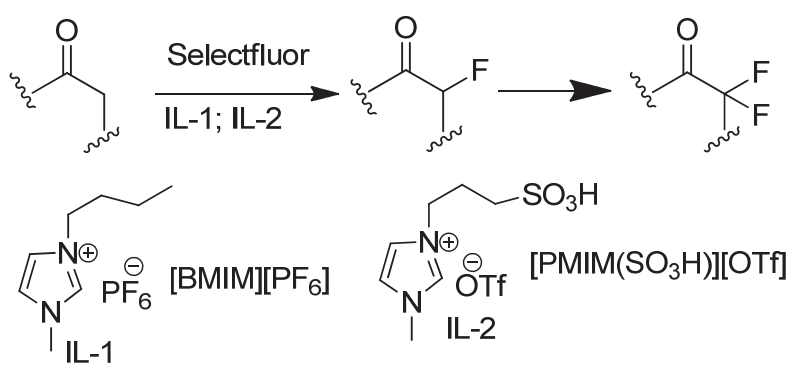

Scheme 9. $\alpha$-Fluorination of carbonyl compounds. 


\section{Synthesis of High Value Small Molecules by Dediazoniative Functionalization}

\subsection{Halo- and Azido-dediazoniation in ILs}

Dediazoniation of $\mathrm{PhN}_{2}{ }^{+} \mathrm{BF}_{4}{ }^{-}$in $[\mathrm{BMIM}]\left[\mathrm{PF}_{6}\right] / \mathrm{TMSX}\left(\mathrm{X}=\mathrm{Br}, \mathrm{I}, \mathrm{N}_{3}\right)$ provided a convenient method for the synthesis of the corresponding halo- and azido-arenes in good yields with minimal formation of $\mathrm{ArF}$ and $\mathrm{ArH}$ (Scheme 10). ${ }^{35}$ The reactions could also be performed starting from the corresponding amines by in-situ diazotization with nitrosonium salts. NMR monitoring of the progress of these reactions provided evidence that TMSX reacts with $[\mathrm{BMIM}]\left[\mathrm{PF}_{6}\right]$ to give TMSF and $\left[\mathrm{ArN}_{2}\right][\mathrm{X}]$ via metathesis. The latter undergoes dediazoniation to produce the corresponding $\mathrm{ArX}$.

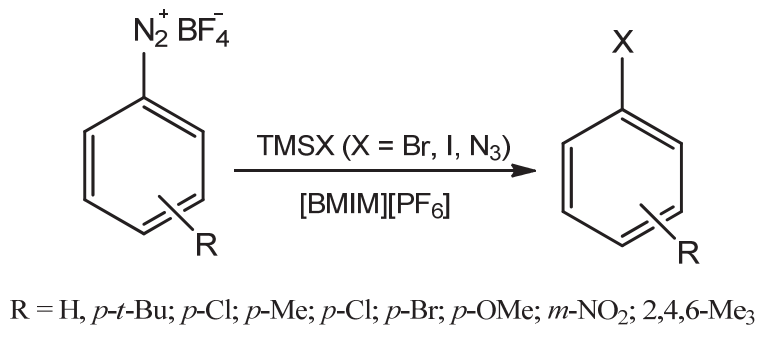

Scheme 10. Halo- and azido-dediazoniation.

\subsection{Dediazoniation in $[\mathrm{BMIM}]\left[\mathrm{NTf}_{2}\right]$}

Dediazoniation of $\left[\mathrm{ArN}_{2}\right]\left[\mathrm{BF}_{4}\right]$ salts in $[\mathrm{BMIM}]\left[\mathrm{NTf}_{2}\right]$ either under thermal or photolytic conditions provided facile access to the corresponding $\mathrm{NTf}_{2}$-derivatives $\mathbf{1}$ and $\mathbf{2}$ (Scheme 11),

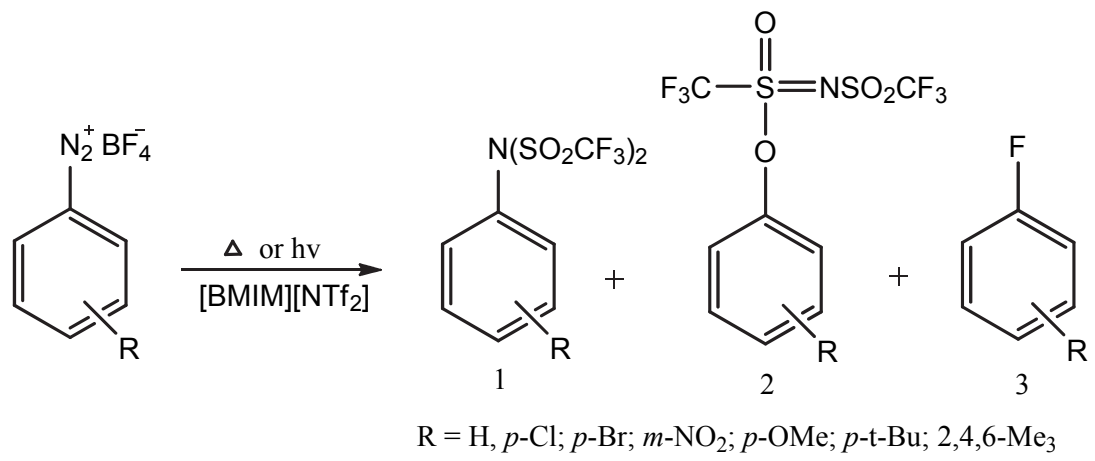

Scheme 11. Dediazoniation in $[\mathrm{BMIM}]\left[\mathrm{NTf}_{2}\right]$.

with the latter as major product, along with minimal amount of the Schiemann product ArF. ${ }^{36}$ This study demonstrated that despite the highly non-nucleophilic character of $\mathrm{NTf}_{2}$ anion it acts as an ambident nucleophile toward $\mathrm{Ar}^{+}$. The process is likely to involve rapid metathesis to form $\left[\mathrm{ArN}_{2}\right]\left[\mathrm{NTf}_{2}\right]$ followed by dediazoniation. It is noteworthy that synthesis of $\mathrm{ArO}-\mathrm{SO}\left(\mathrm{CF}_{3}\right)=\mathrm{NTf}$ 
compounds by other means is highly challenging, and the present method underscores the power of the IL method to get easy access to this compound through in-situ metathesis and dediazoniation.

\section{Aromatic Halogenation}

\subsection{Chlorination of Arenes with Trichloroisocyanuric acid (TCICA)}

Trichloroisocyanuric acid (TCICA), a readily available, cheap, industrial chemical, was used in combination with Brønsted acidic IL $\left[\mathrm{BMIM}\left(\mathrm{SO}_{3} \mathrm{H}\right][\mathrm{OTf}]\right.$ for chlorination of aromatics under mild conditions in good to excellent yields (Scheme 12). ${ }^{37}$ The mono- versus di-chlorination was tuned by changing the arene to TCICA ratio (Table 1). This transformation benefits from high atom economy by producing three moles of $\mathrm{ArCl}$ from each mole of TCICA.

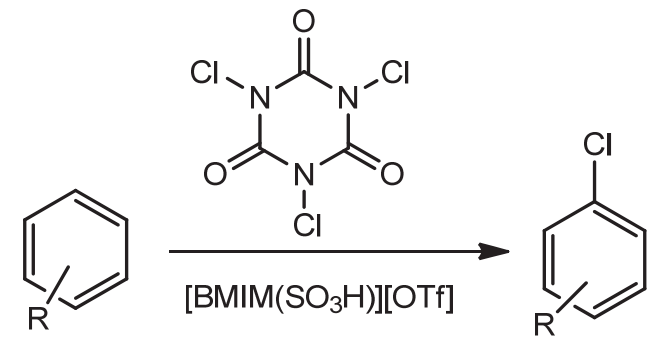

$$
\begin{gathered}
\mathrm{R}=\mathrm{H} ; \mathrm{Me} ; \mathrm{OMe} ; \mathrm{Et} ; 1,3,5-\mathrm{Me}_{3} ; 1,4-\mathrm{Me}_{2} ; 1,3,5,6-\mathrm{Me}_{4} ; 1,4-\mathrm{Et}_{2} ; \\
\text { 4-F/1-OMe; } \mathrm{p}-\mathrm{Cl} ; 4-\mathrm{NO}_{2} / 1-\mathrm{OMe}
\end{gathered}
$$

Scheme 12. Aromatic chlorination with TCICA catalyzed by Brønsted acidic IL.

\begin{tabular}{|c|c|c|c|c|c|c|}
\hline \multirow{2}{*}{ Substrate } & \multirow{2}{*}{$\begin{array}{c}\text { Ar:TCICA:IL } \\
\text { (mol. ratio) }\end{array}$} & \multirow{2}{*}{$\begin{array}{l}\text { Time } \\
\text { (h) }\end{array}$} & \multirow{2}{*}{$\begin{array}{l}\text { Temp. } \\
\left({ }^{\circ} \mathrm{C}\right)\end{array}$} & \multicolumn{2}{|c|}{ Product yields $(\%)$} & \multirow{2}{*}{ Trichlorinated } \\
\hline & & & & Monochlorinated & Dichlorinated & \\
\hline \multirow[t]{3}{*}{ Anisole } & $3.0: 1.0: 25.0$ & 6 & $49-50$ & 96 & 2 & - \\
\hline & $1.0: 1.0: 25.0$ & 20 & $49-50$ & $<1$ & 75 & 24 \\
\hline & $1.0: 2.0: 25.0$ & 70 & $52-50$ & 4 & 20 & 76 \\
\hline \multirow[t]{2}{*}{ Mesitylene } & $3.0: 1.0: 25.0$ & 20 & $52-50$ & 46 & 19 & - \\
\hline & $1.0: 2.0: 25.0$ & 70 & $60-55$ & 1 & 93 & 1 \\
\hline \multirow[t]{2}{*}{$\underline{p}$-Xylene } & $1.0: 1.0: 25.0$ & 48 & $56-58$ & 72 & 14 & - \\
\hline & $1.0: 1.0: 25.0$ & 70 & $49-54$ & 17 & 75 & - \\
\hline \multirow[t]{2}{*}{ TMB } & $3.0: 1.0: 25.0$ & 20 & $52-57$ & 12 & 32 & - \\
\hline & $1.0: 1.0: 25.0$ & 48 & $42-40$ & 2 & 74 & - \\
\hline
\end{tabular}

Table 1 
Whereas activated and moderately activated alkyl- and halo-benzenes were successfully mono- and di-chlorinated by using this method, nitrobenzene did not react. A triprotonated/protosolvated TCICA was proposed as key intermediate for these reactions (Scheme 13). DFT calculations suggested that sequential $[\mathrm{N}-\mathrm{Cl}]^{+}$bond cleavage followed by $\mathrm{N}-$ protonation is energetically favorable and exhibit negative enthalpy for a trication. By contrast $\mathrm{Cl}^{+}$transfer from the dication and monocation were increasingly more endothermic showing positive $\Delta \mathrm{G}$ and $\Delta \mathrm{H}$ values.<smiles>O=c1n(Cl)c(=O)n(Cl)c(=O)n1Cl</smiles>

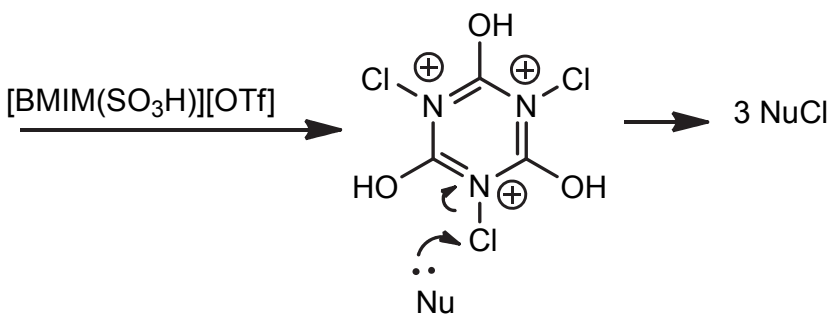

Scheme 13. Triprotonated/protosolvated TCICA as transfer-chlorinating agent.

\subsection{Halofunctionalization with $\mathrm{I}_{2} / \mathrm{H}_{2} \mathrm{O}_{2}$ and with $\mathrm{N}$-halosuccinimides (NXS)}

In joint projects with collaborators in Slovenia a convenient high yielding method for iodofunctionalization of activated aromatics was developed by using elemental iodine with $\mathrm{H}_{2} \mathrm{O}_{2}$

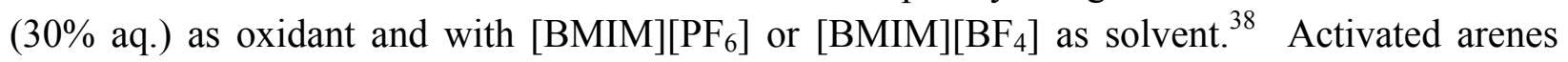
were ring iodinated whereas arylalkyl ketones were regioselectively iodinated alpha to carbonyl. ${ }^{38}$ In another study it was shown that $\left[\mathrm{BMIM}\left(\mathrm{SO}_{3} \mathrm{H}\right)\right][\mathrm{OTf}]$ acts as solvent and catalysts in halogenation of activated organic compounds with NXS (Scheme 14) ${ }^{39}$ In both cases the ILs could be reused several times with no noticeable decrease in efficiency.

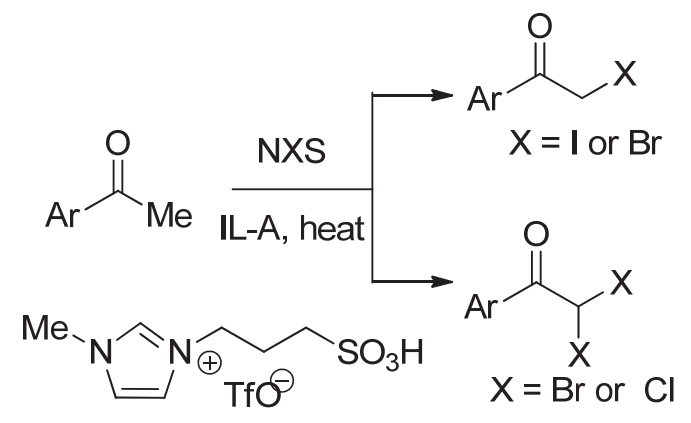

$\left[\mathrm{BMIM}\left(\mathrm{SO}_{3} \mathrm{H}\right)\right][\mathrm{OTf}]$

\section{IL-A}

Scheme 14. Brønsted acidic IL-mediated halofunctionalization. 


\subsection{Metal and $\mathrm{H}_{2} \mathrm{O}_{2}$ free aerobic oxidative aromatic halogenation}

In another joint effort, an efficient and green method was introduced for aerobic oxidative halogenation of arenes under mild conditions and in high yields by employing multi-functional ILs $\left[\mathrm{RNH}_{3}{ }^{+}\right]\left[\mathrm{NO}_{3}{ }^{-}\right] / \mathrm{HX}$ and $\left[\mathrm{BMIM}\left(\mathrm{SO}_{3} \mathrm{H}\right)\right]\left[\left(\mathrm{NO}_{3}\right)_{\mathrm{x}}(\mathrm{X})_{\mathrm{y}}\right](\mathrm{X}=\mathrm{Br}, \mathrm{Cl})$ as solvent and promoter (Scheme 15). ${ }^{40}$ These are prepared in situ by addition of $\mathrm{HBr}$ or $\mathrm{HCl}$ to ethyl- or propylammonium nitrate $(\mathrm{EAN}$ or $\mathrm{PAN})$, and to $\left[\mathrm{BMIM}\left(\mathrm{SO}_{3} \mathrm{H}\right)\right]\left[\mathrm{NO}_{3}\right]$. The reactions could be repeated over several cycles.

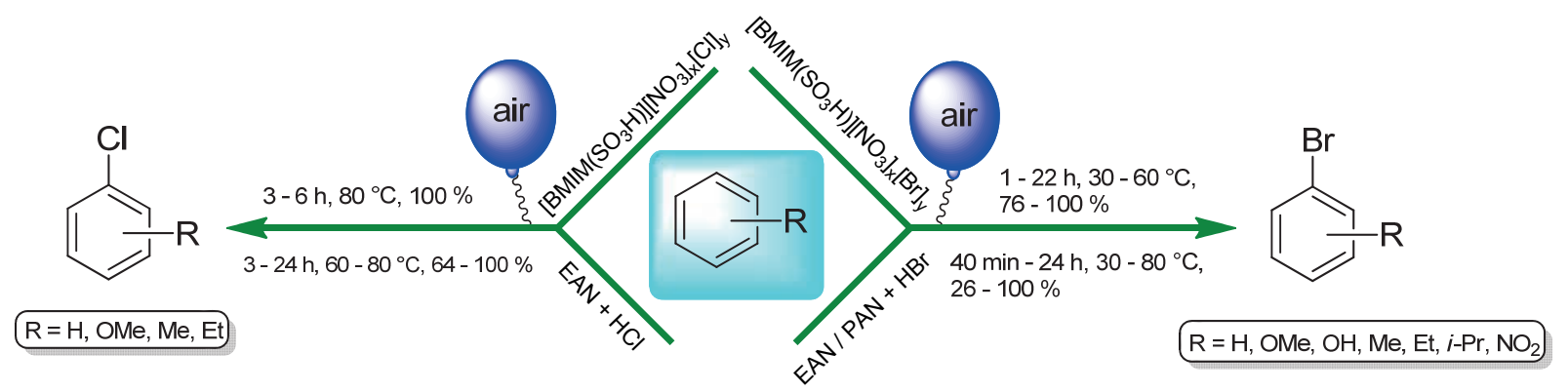

Scheme 15. Aerobic oxidative halogenation of arenes.

\section{Catalysis by Metallic Triflates and Brønsted Acidic IL}

\subsection{The Ritter Reaction}

The Brønsted acidic IL $\left[\mathrm{BMIM}\left(\mathrm{SO}_{3} \mathrm{H}\right)\right][\mathrm{OTf}]$ was used as catalyst to synthesize a variety of amides via the Ritter reaction of alcohols (Scheme 16). Reaction of $\mathrm{NOPF}_{6}$ with $\mathrm{RBr}$ and with adamantane in $[\mathrm{BMIM}]\left[\mathrm{PF}_{6}\right]$ provided alternative means of carbocation generation in the IL. ${ }^{41}$

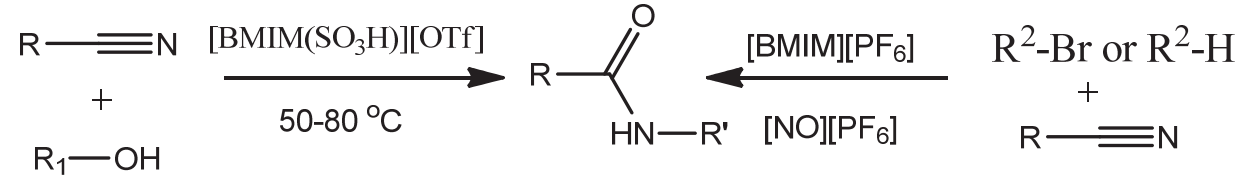

$\mathrm{R}=\mathrm{Me} ; \mathrm{Et} ; \mathrm{Cy} ; \mathrm{Ada} ; \mathrm{Ph} ; \mathrm{OMePh}$; furanyl; pyridyl

$\mathrm{R}^{1}=\mathrm{tBu}$; adamantyl; methylcyclopentyl

$\mathrm{R}^{2}=\mathrm{tBu}$; adamantyl

Scheme 16. Synthesis of amides via the Ritter reaction in IL.

\subsection{The Schmidt reaction of aldehydes}

A new high yielding method for the conversion of structurally diverse aromatic and heteroaromatic aldehydes to nitriles was developed via the Schmidt reaction by using $\mathrm{TMSN}_{3}$, IL-1 as solvent, and IL-2 as catalysts, with recycling and reuse of IL-1 (Scheme 17). ${ }^{42}$ 


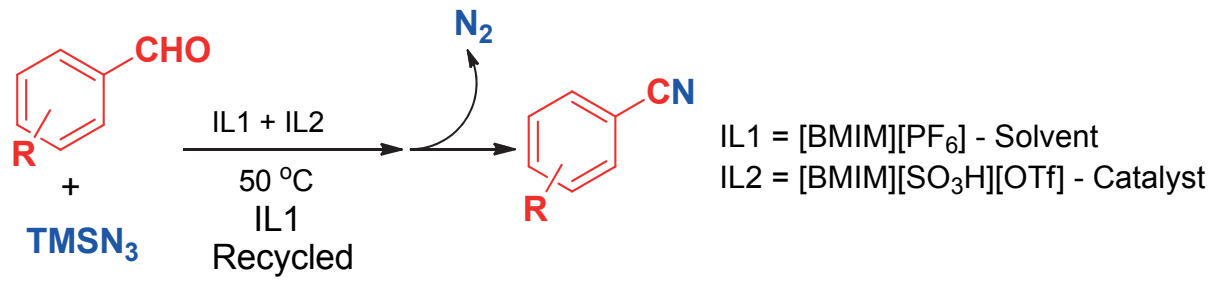

Scheme 17. Schmidt reaction of aldehydes.

\subsection{Rearrangement of 1,2-diaryl epoxides}

The aryl versus $\mathrm{H}$ migration pathways in the rearrangement of trans-stilbene oxide as well as a series of singly substituted 1,2-diphenyl-oxiranes were studied in various BMIM-ILs and in DCM as solvents. Metallic triflates, in particular $\mathrm{Bi}(\mathrm{OTf})_{3}$, and Brønsted acid IL $\left[\mathrm{BMIM}\left(\mathrm{SO}_{3} \mathrm{H}\right)\right][\mathrm{OTf}]$ proved highly efficient as catalyst for this transformation. Reactions were also performed without promoter by using microwave (Scheme 18). ${ }^{43}$ In the majority of cases selective formation of aryl migration products (aldehydes) were observed. Ketone formation $(\mathrm{H}$ migration) was observed with the $p-\mathrm{CN}$ and $p-\mathrm{NO}_{2}$ derivatives, and under $\mathrm{MW}$ in $[\mathrm{BMIM}]\left[\mathrm{PF}_{6}\right]$ solvent. The study identified new methods and reagents for catalytic and regioselective conversion of 1,2-diarylepoxide to carbonyl compounds.

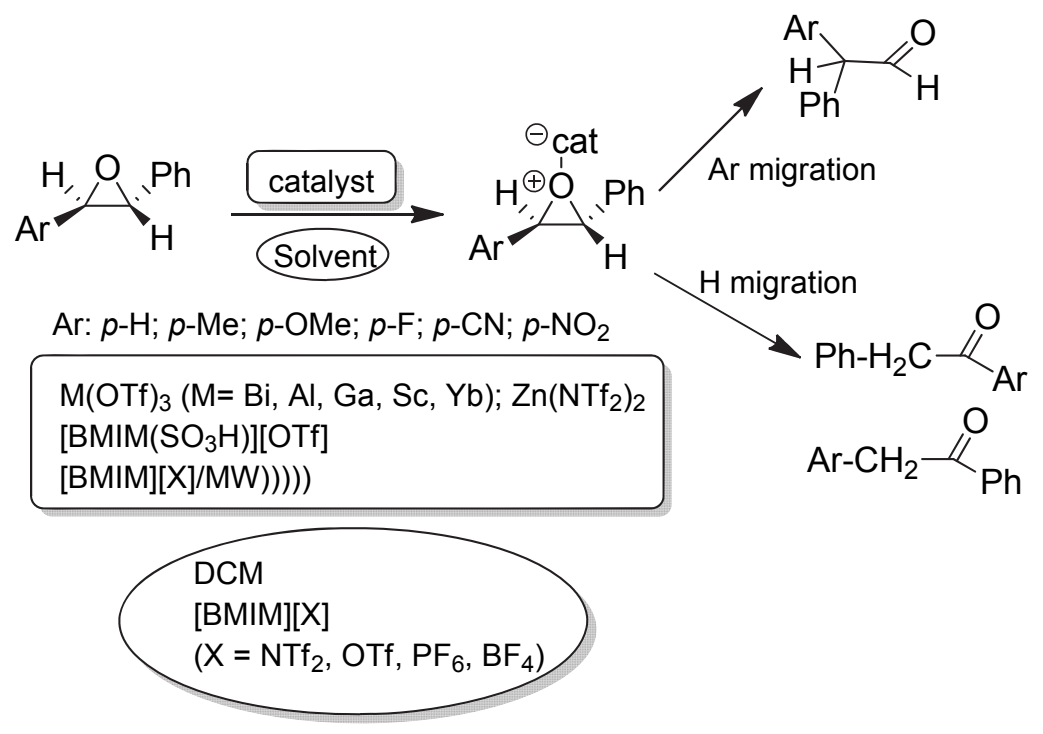

Scheme 18. Rearrangement of 1,2-diaryl epoxides.

\subsection{Building heterocyclic systems}

The $\mathrm{RC}(\mathrm{OR})_{2}{ }^{+}$cations generated in-situ by ionization of orthocarboxylic acid esters in Brønsted acid ILs $\left[\mathrm{EtNH}_{3}\right]\left[\mathrm{NO}_{3}\right]$ "EAN" or $\left[\mathrm{PMIM}\left(\mathrm{SO}_{3} \mathrm{H}\right)\right][\mathrm{OTf}]$ were used as building blocks for facile synthesis of tetrazoles, benzazoles, and other ring systems (Scheme 19). ${ }^{44}$ This method provided 
easy access to a library of $1 H$-1,2,3,4-tetrazoles and benzazoles, as well as a series of quinazolinones form readily available building blocks.

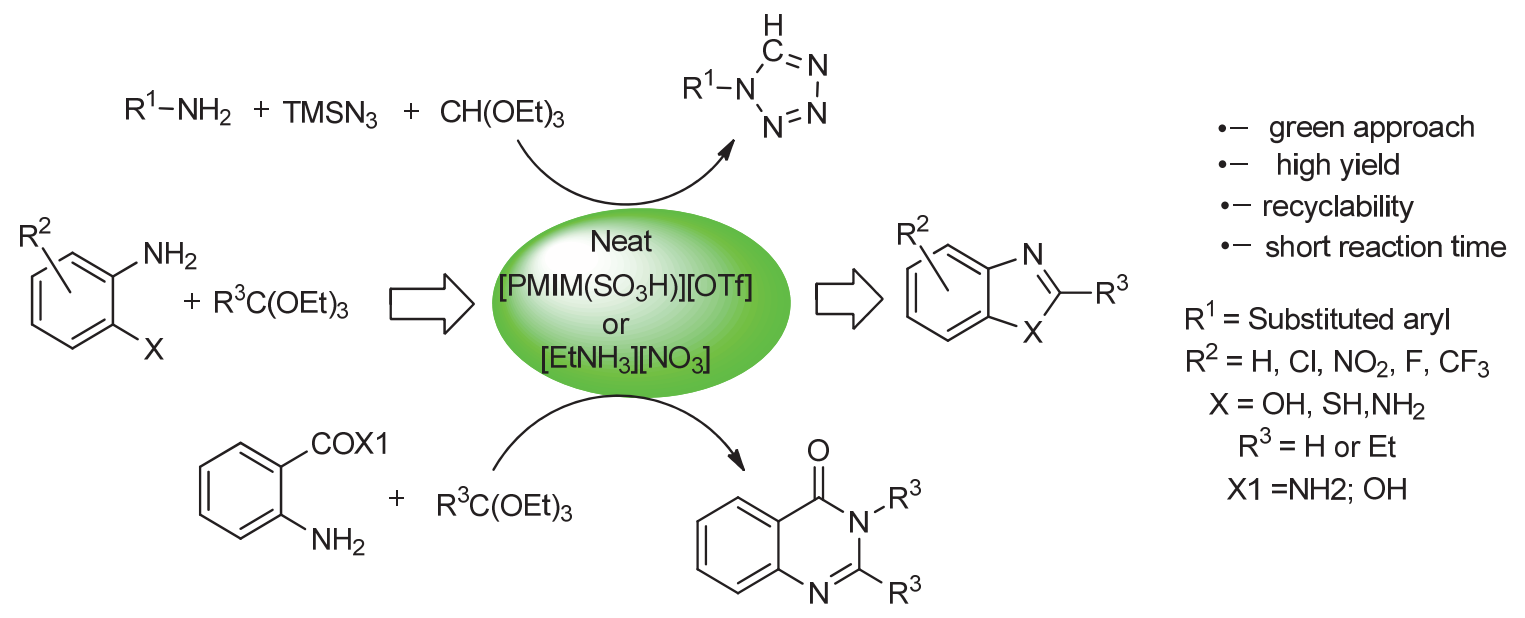

Scheme 19. Building heterocyclic systems with $\mathrm{RC}(\mathrm{OR})_{2}$.

\section{Tetrazoles and tetrazolium-based ILs}

A series of 5 -substituted $1 H$-tetrazoles were prepared via click chemistry employing $\mathrm{Cu}-\mathrm{Zn}$ alloy nanopowder. These were alkylated in DMF to form the 1,5- and 2,5-disubstituted tetrazoles. Subsequent $\mathrm{N}$-alkylation with EtOTf or $\mathrm{Et}_{2} \mathrm{SO}_{4}$ furnished the corresponding tetrazolium salts. The $\mathrm{NTf}_{2}$ salts were synthesized by metathesis with $\operatorname{LiNTf}_{2}($ Scheme 20$){ }^{45}$

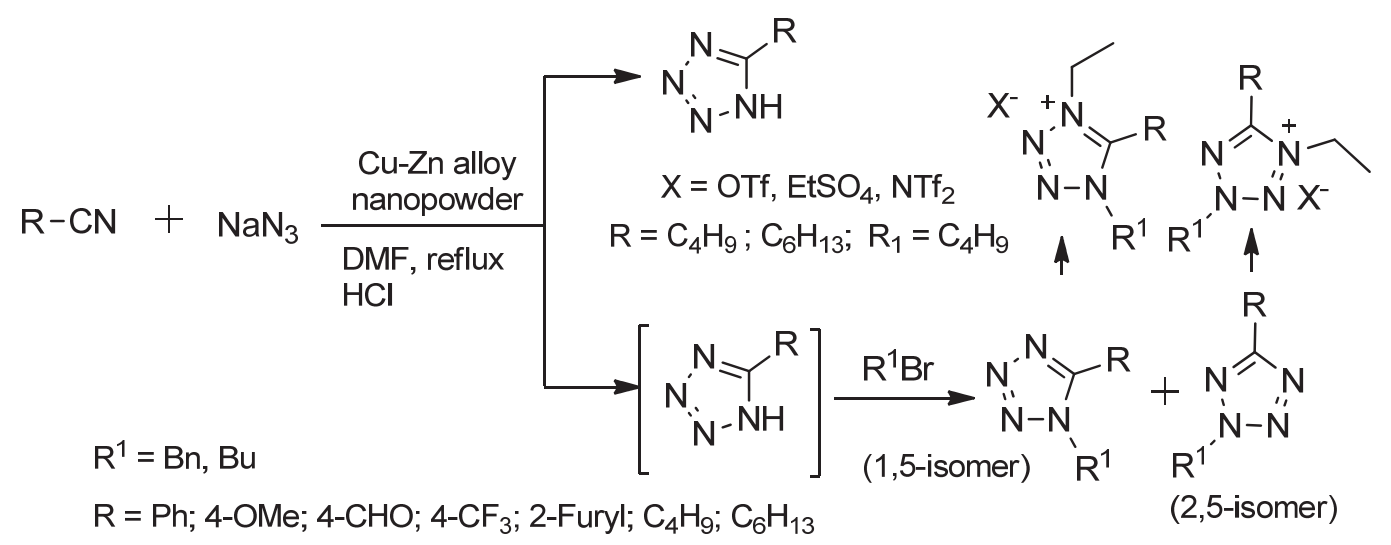

Scheme 20. Tetrazoles and tetrazolium ionic liquids. 


\section{Development of Facile Propargylation Methods in ILs}

The discovery that propargylic alcohols are efficiently ionized in imidazolium-ILs by addition of catalytic amounts of metallic triflates, TfOH, or Brønsted acid IL to form "tamed" propargylic cations, enabled the development of a number of IL-based methods for the synthesis of a wide variety of propargylated small molecule building blocks.

\subsection{Propargylated Arenes, Heteroarenes, and Ethers}

Arenes and heteroarenes were efficiently propargylated, and a host of symmetrical and unsymmetrical propargylated ethers were prepared by coupling two propargyl alcohols or by coupling a propargyl alcohol with a primary or secondary alcohol (Scheme 21). ${ }^{46}$

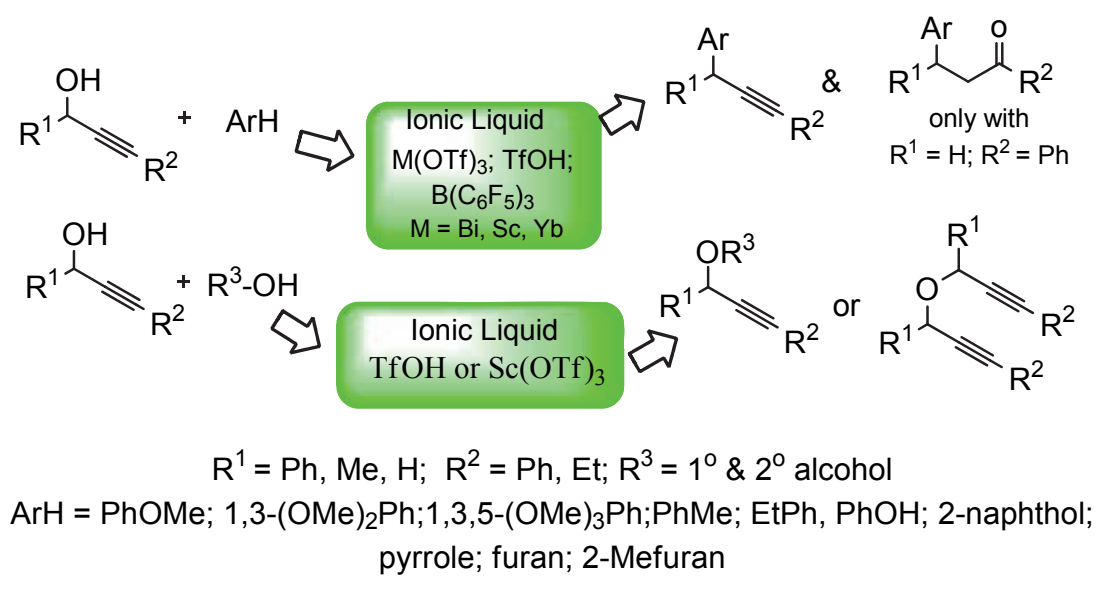

Scheme 21. Propargylation of arenes and heteroarenes, and synthesis of dipropargylic ethers.

\subsection{Propargylation of 1,3-Dicarbonyl Compounds and 4-Hydroxycoumarin}

Condensation of propargylic alcohols with 1,3-diketones and $\beta$-ketoesters were effected in $[\mathrm{BMIM}]\left[\mathrm{PF}_{6}\right]$ or EAN as solvent, with metallic triflates as catalyst (Scheme 22) ${ }^{47}$ Concomitant cycloisomerization, leading to tetrasubstituted furans, was observed with some propargylic alcohols. Bismuth nitrate proved efficient for propargylation of 4-hydroxycoumarin (Scheme 22). ${ }^{47}$

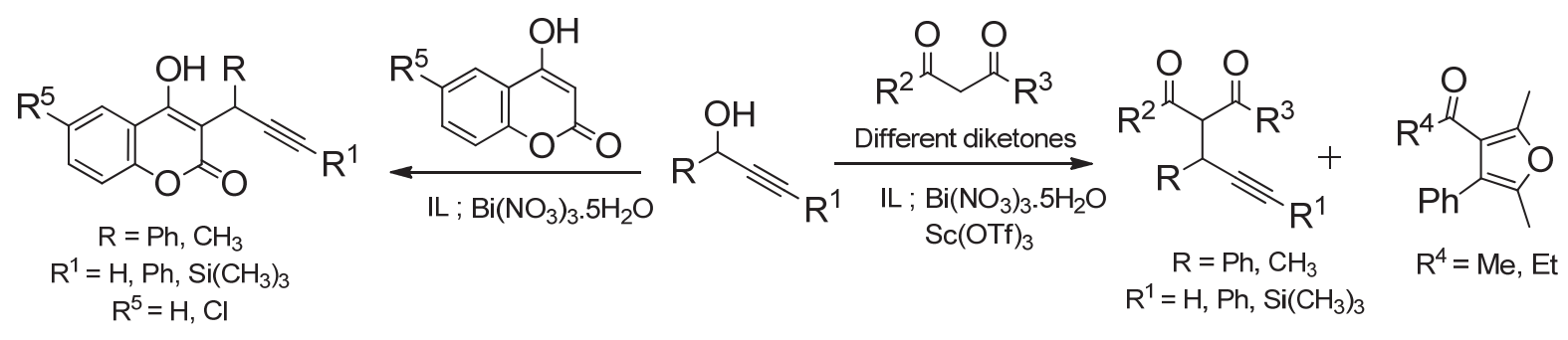

Scheme 22. Propargylation of 1,3-dicarbonyl compounds and 4-hydroxycoumarin. 


\subsection{Propargylation of indoles and carbazole}

Convenient methods were developed for the synthesis of propargylated indoles and carbazole by employing bismuth nitrate as catalyst and $[\mathrm{BMIM}]\left[\mathrm{PF}_{6}\right]$ as solvent. Dipropargylation of carbazole was achieved when $\mathrm{TfOH}$ was used as catalysts in place of bismuth nitrate. The IL solvent could be recovered and reused (Scheme 23). ${ }^{48,49}$

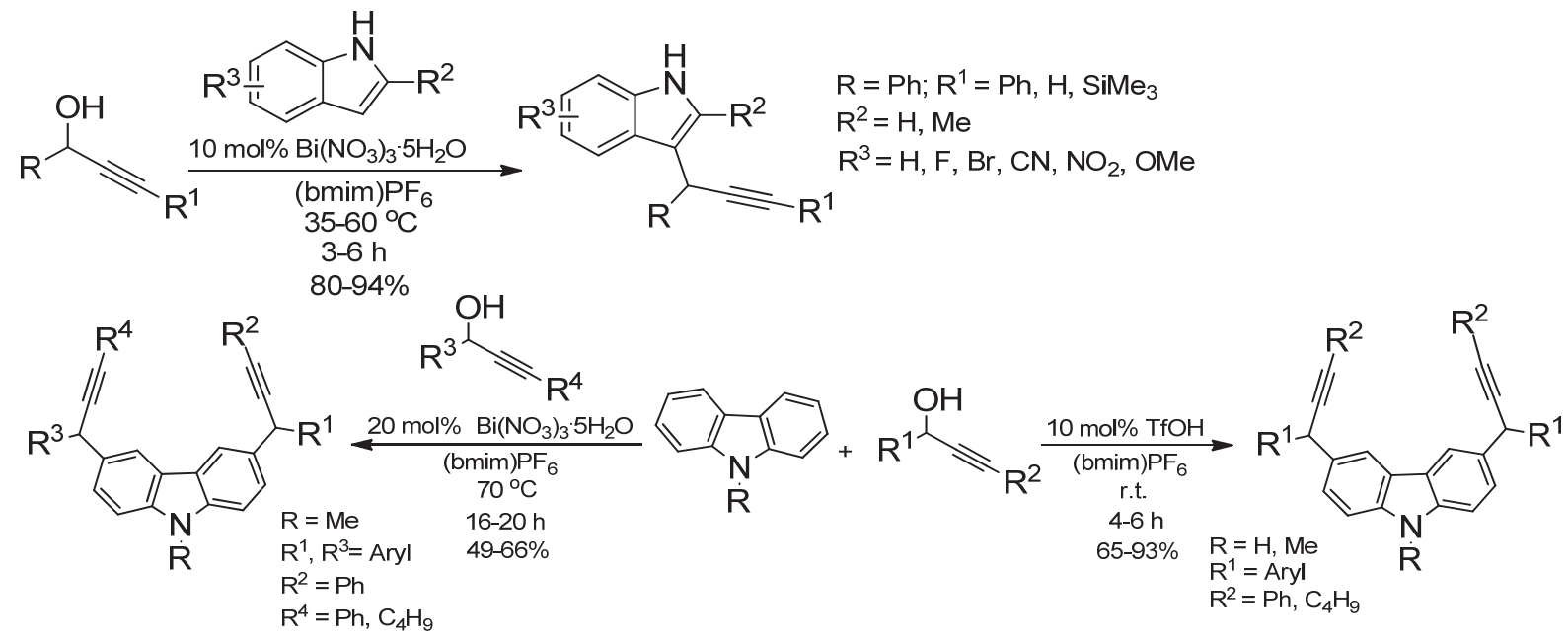

Scheme 23. Propargylation of indoles and mono- and di-propargylation of carbazoles.

\subsection{Coupling of allyl- and alkynylsilanes with propargylic, allylic and benzylic alcohols}

The 1,5-Enynes were prepared in respectable yields by coupling propargylic alcohols with allylTMS, employing Bi(OTf $)_{3}$ in IL solvent. Similarly, allylic and benzylic alcohols were coupled to allyl- and alkynylsilanes. ${ }^{49}$ A host of propargylic, propargylic/allylic, bis-allylic, allylic, and benzylic alcohols were reduced with $\mathrm{Et}_{3} \mathrm{SiH}$ by using $\mathrm{Bi}(\mathrm{OTf})_{3} /[\mathrm{BMIM}]\left[\mathrm{BF}_{4}\right]\left(\mathrm{Scheme}_{24)}{ }^{50}\right.$

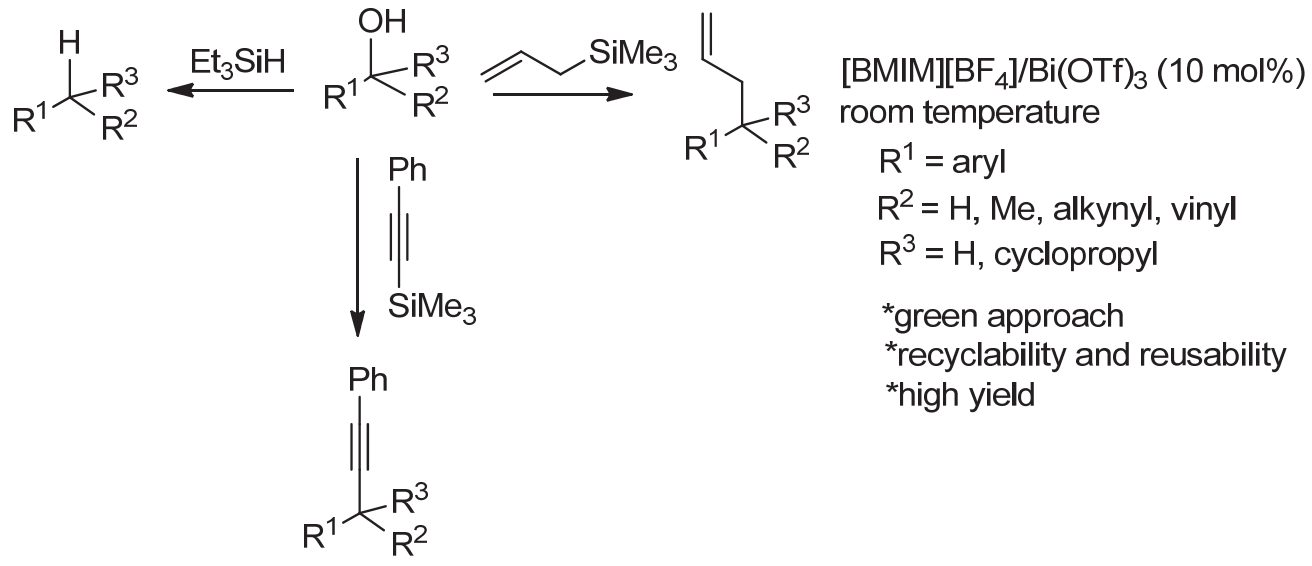

Scheme 24. Reactions of propargylic, allylic, and benzylic alcohols with allyl and alkynyl silanes in IL solvent. 


\subsection{Metal-free Rupe rearrangement in ILs}

An IL-based protocol for the one-pot synthesis $\alpha, \beta$-enones from a diverse set of cyclic and acylic propargylic alcohols via the Rupe rearrangement was developed by employing [BMIM] $\left[\mathrm{PF}_{6}\right]$ as solvent and $\left[\mathrm{BMIM}\left(\mathrm{SO}_{3} \mathrm{H}\right)\right][\mathrm{OTf}]$ as catalyst with recycling and reuse of the solvent. In selected cases the resulting enone reacted with benzaldehyde via a metal-free Rupe-aldol-Nazarav sequence to form indenone (Scheme 25). ${ }^{51}$

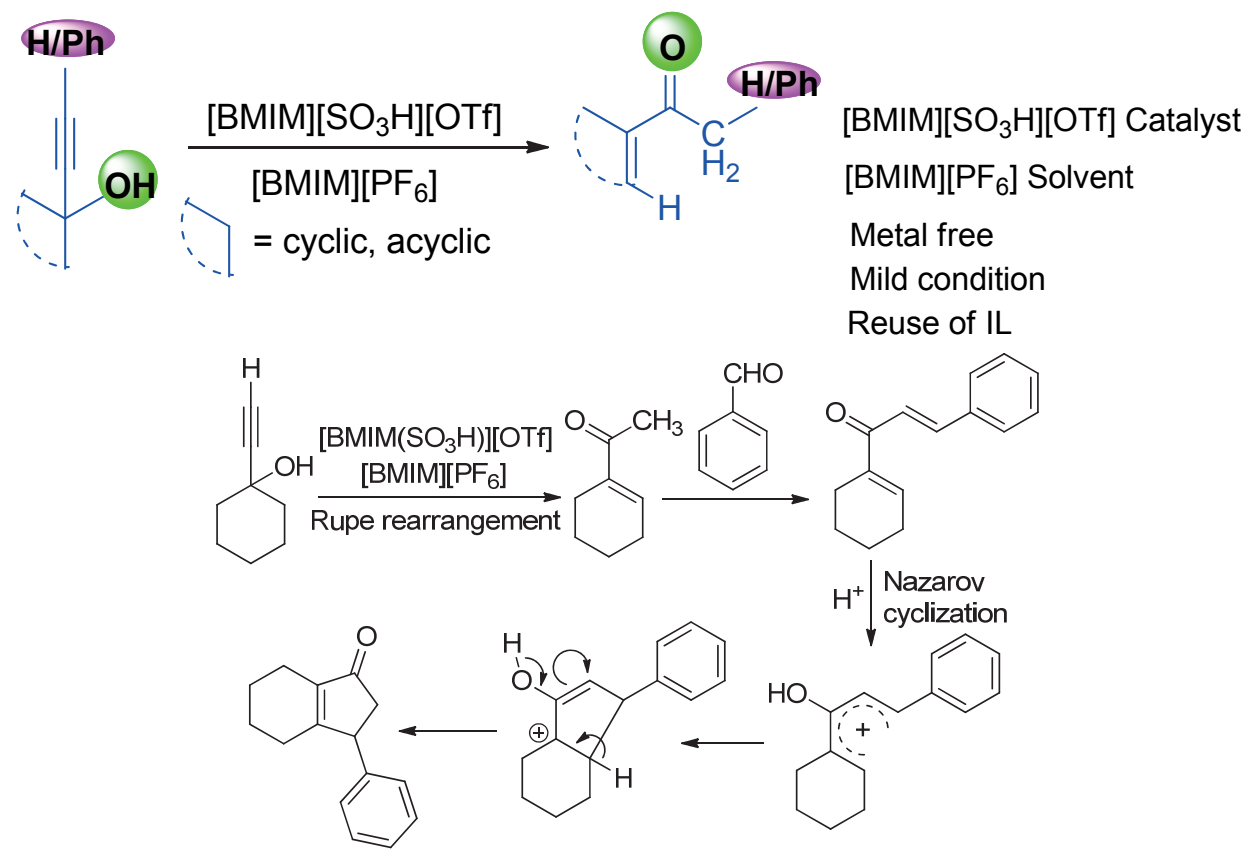

Scheme 25. Mild conversion of propargylic alcohols to cyclic and acyclic enones via the Rupe rearrangement in ILs, and a one-pot Rupe-aldol-Nazarov sequence leading to 3-phenylhexahydroindenone.

\section{Metal Mediated Cross-Coupling Reactions and Cyclizations in ILs}

By employing arenediazonium salts as coupling partners, $\mathrm{Pd}(\mathrm{OAc})_{2}$ as catalyst, and $[\mathrm{BMIM}]\left[\mathrm{PF}_{6}\right]$ or $[\mathrm{BMIM}]\left[\mathrm{BF}_{4}\right]$ as solvent, a convenient IL-based method was developed for olefin synthesis (Scheme 26). ${ }^{52}$ 


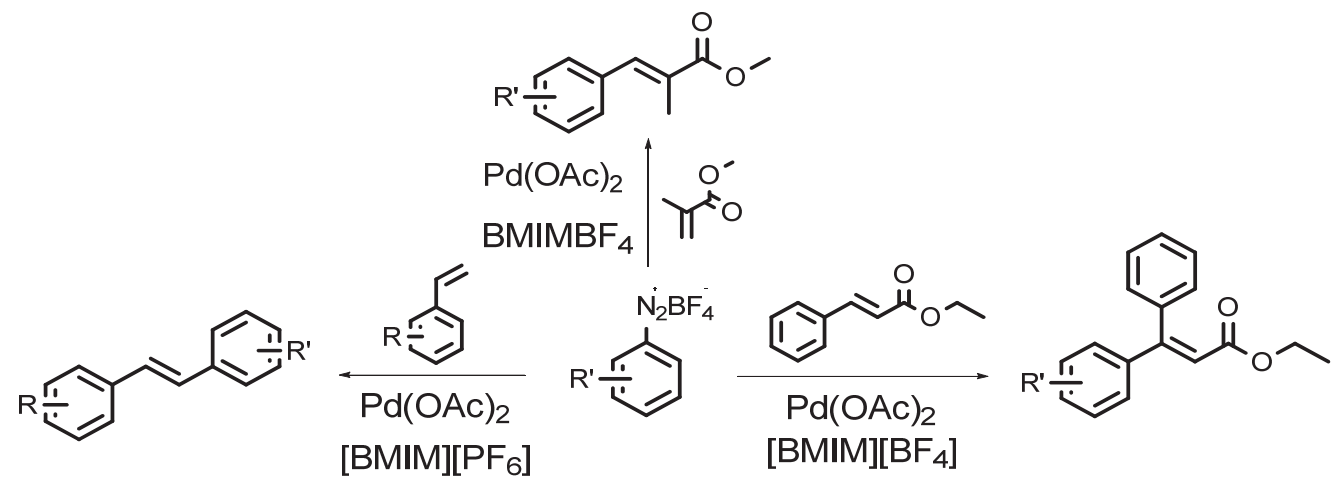

Scheme 26. Heck coupling by using $\mathrm{ArN}_{2}{ }^{+}$salts in IL solvents.

In another study, polyfluoroarenes were coupled with simple arenes in the IL solvent by using catalytic amounts of $\mathrm{Pd}(\mathrm{OAc})_{2}$ (Scheme 27). ${ }^{53}$<smiles>Fc1c(F)c(F)c(Br)c(F)c1F</smiles>

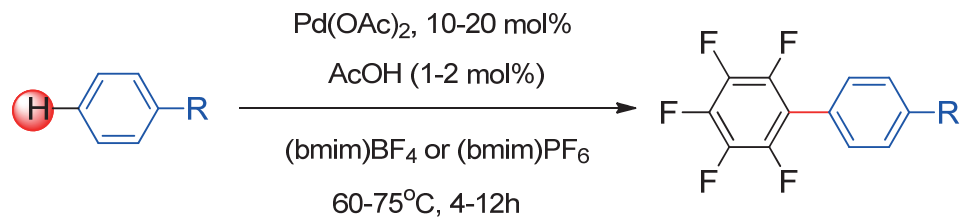

Scheme 27. Cross coupling of polyfluoroarenes.

By using a piperidine-tethered imidazolium-IL as dual solvent and base, Sonogashira crosscoupling between ArI and a variety of alkynes were effected without copper, external base, or additive. The method was applied to the synthesis of $\mathrm{SF}_{5}$-substituted alkynes (Scheme 28). ${ }^{54}$

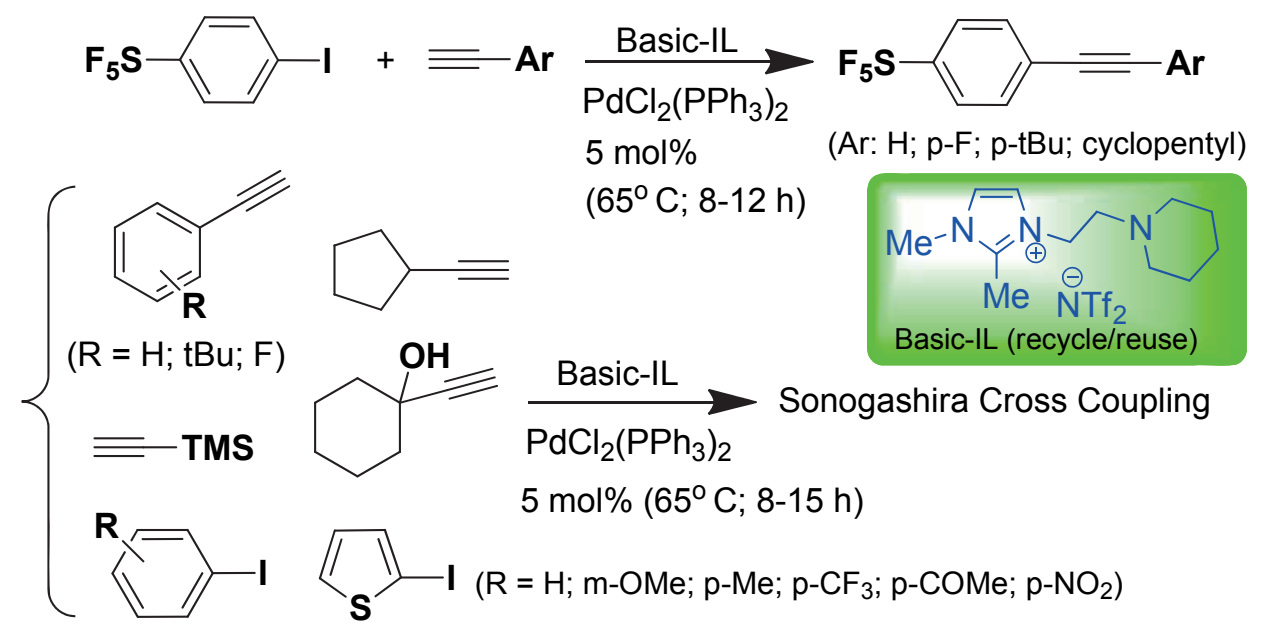

Scheme 28. Sonogashira cross-coupling by using a task-specific IL. 
A facile $\mathrm{Pd}(\mathrm{OAc})_{2}$ catalyzed method for the conversion of Schiff bases to 2-aryl- and 2heteroarylbenzoxazoles and benzthiazoles was also developed (Scheme 29). ${ }^{55}$

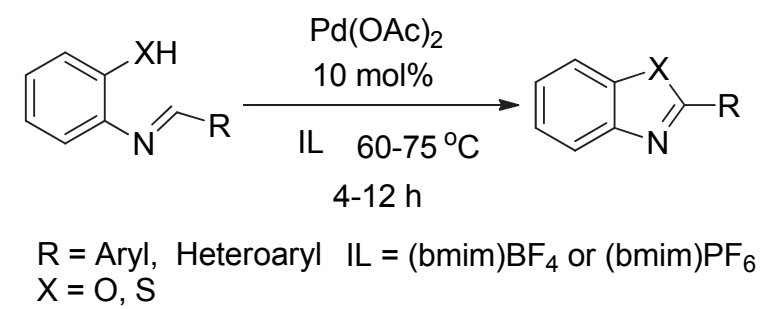

Scheme 29. Facile metal-mediated conversion of Schiff bases to benzoxazoles and benzthiazoles.

\section{Summary}

The present account gives a glimpse into the various projects carried out in my laboratory on the development of synthetic methods that utilize ionic liquids as solvent. Combination of an IL acting as solvent, and a Brønsted-acidic IL or a metallic triflate acting as catalyst, offers interesting possibilities for developing synthetic methods involving carbocations and onium ions. The finding that onium salts can be dissolved in imidazolium-ILs has opened up new and improved prospects in fluorination and in diazonium ion chemistry including metal-mediated coupling reactions. The recycling and reuse of the IL solvent provides an added advantage.

\section{Acknowledgements}

I am grateful to the postdocs, visiting scientists, visiting $\mathrm{PhD}$ students, and several undergraduates who worked on various ionic liquid projects in my group at Kent State and later at University of North Florida, whose names appear in the references cited. I acknowledge fruitful collaborations and joint publications with Stojan Stavber and his group in Slovenia. Our nitration work was supported by a grant from the Army Research Office. ACS-Moissan SURF awards and RSC travel grants facilitated some of our efforts. A recent NSF-MRI grant enabled the acquisition of an X-ray facility at UNF. I am thankful to UNF for the Presidential Professorship award and for research support.

\section{References}

1. Welton, T. Chem. Rev. 1999, 99, 2071-2083. http://dx.doi.org/10.1021/cr980032t 
2. Hagiwara, R.; Ito, Y. J. Fluorine Chem. 2000, 105, 221-227.

http://dx.doi.org/10.1016/S0022-1139(99)00267-5

3. Sheldon, R. Chem.Comm. 2001, 2399-2407

4. Zhao, H.; Malhotra, S. V. Aldrichim. Acta 2002, 35, 75-83.

http://dx.doi.org/10.1016/S0003-2670(01)01543-4

5. Dupont, J.; de Souza, R. F.; Suarez, P. A. Z. Chem. Rev. 2002, 102, 3667-3692.

http://dx.doi.org/10.1021/cr010338r

6. Olivier-Bourbigou, H.; Magna, L. J. Mol. Catal. A: Chem. 2002, 182-183, 419-437. http://dx.doi.org/10.1016/S1381-1169(01)00465-4

7. Bartsch, R. A.; Dzyuba, S. V. Angew. Chem. Int. Ed. 2003, 42, 148-150. http://dx.doi.org/10.1002/anie.200390070

8. Forsyth, A. A.; Pringle, J. M.; MacFarlane, D. R. Aust. J. Chem. 2004, 57, 113-119. http://dx.doi.org/10.1071/CH03231

9. Chiappe, C.; Pieraccini, D. J. Phys.Org.Chem. 2005, 18, 275-297. http://dx.doi.org/10.1002/poc.863

10. Ding, J.; Armstrong, D. W. Chirality 2005, 17, 281-292. http://dx.doi.org/10.1002/chir.20153

11. Xue, H.; Shreeve, J. M. J. Fluorine Chem. 2006, 127, 159-176. http://dx.doi.org/10.1016/j.jfluchem.2005.11.007

12. Borodkin, G. I., Shubin, V. G. Russ. J. Org. Chem. 2006, 42, 1745-1770. http://dx.doi.org/10.1134/S1070428006120013

13. Enders, F.; El Adedin, S. Z. Phys.Chem.Chem.Phys. 2006, 8, 2101-2116. http://dx.doi.org/10.1039/b600519p

14. Martins, M. A. P.; Frizzo, C.P.; Moreira, D. N.; Zanatta, N.; Bonacorso, H. G. Chem. Rev. 2008, 108, 2015-2050. http://dx.doi.org/10.1021/cr078399y

15. Plechkova, N. V.; Seddon, K. R. Chem. Soc. Rev. 2008, 37, 123-150. http://dx.doi.org/10.1039/B006677J

16. Greaves, T. L.; Drummond, C. J. Chem. Rev. 2008, 108, 206-237. http://dx.doi.org/10.1021/cr068040u

17. Pavlinac, J.; Zupan, M.; Laali, K. K.; Stavber, S. Tetrahedron 2009, 65, 5625-5662. http://dx.doi.org/10.1016/j.tet.2009.04.092

18. Olivier-Bourbigou, H.; Magna, L.; Morvan, D. Applied Catalysis A: General 2010, 373, 156. http://dx.doi.org/10.1016/j.apcata.2009.10.008

19. Hallett, J. P.; Welton, T. Chem. Rev. 2011, 111, 3508-3576. http://dx.doi.org/10.1021/cr1003248

20. Chiappe, C.; Rajamani, S. Eur. J. Org. Chem. 2011, 5517-5539. http://dx.doi.org/10.1002/ejoc.201100432 
21. Pereiro, A. B.; Araujo, J. M. M.; Martinho, S.; Alves, F.; Nunes, S.; Matias, A.; Duarte, C. M. M.; Rebelo, L. P. N.; Marrucho, I. M. ACS Sustainable Chem. Eng. 2013, 1, 427-439. http://dx.doi.org/10.1021/sc300163n

22. Smiglak, M.; Pringle, J. M.; Lu, X.; Han, L.; Zhang, S.; Gao, H.; MacFarlane D. R.; Rogers, R. D. Chem. Comm. 2014, 50, 9228-9250. http://dx.doi.org/10.1039/C4CC02021A

23. Tran, A. N.; Van Do, T.-N.; My Le, L.-P.; Le, T. N. J. Fluorine Chem. 2014, 164, 38-43. http://dx.doi.org/10.1016/j.jfluchem.2014.05.005

24. Chiappe, C.; Pomelli, C. S. Eur. J. Org. Chem. 2014, 6120-6139. http://dx.doi.org/10.1002/ejoc.201402093

25. Garcia-Alvarez, J.; Hevia, E.; Capriati, V. Eur. J. Org. Chem. 2015, 6779-6799. http://dx.doi.org/10.1002/ejoc.201500757

26. Laali, K. K.; Gettwert, V. J. J. Org. Chem. 2001, 66, 35-40. http://dx.doi.org/10.1021/jo000523p

27. Aridoss, G.; Laali, K. K. J. Org. Chem. 2011, 76, 8088-8094. http://dx.doi.org/10.1021/jo201374a

28. Jacoway, J.; Narayana Kumar, G. G. K. S.; Laali, K. K. Tetrahedron Lett. 2012, 53, 67826785. http://dx.doi.org/10.1016/j.tetlet.2012.09.137

29. (a) Sarca, V. D.; Laali, K. K. Green Chem. 2006, 8, 615-620. http://dx.doi.org/10.1039/b603176e

30. (b) Yamato, T.; Hideshima, C.; Prakash, G. K. S.; Olah, G. A. J. Org. Chem. 1991, 56, 2089-2091. http://dx.doi.org/10.1021/jo00006a023

31. Laali, K. K.; Sarca, V. D.; Okazaki,T.; Brock, A.; Der, P. Org. Biomol. Chem. 2005, 3, 1034-1042. http://dx.doi.org/10.1039/b416997b

32. Sarca, V. D.; Laali. K. K. Green Chem. 2004, 6, 245-248. http://dx.doi.org/10.1039/b400113c

33. Laali, K. K.; Gettwert, V. J. J. Fluorine Chem. 2001, 107, 31-34. http://dx.doi.org/10.1016/S0022-1139(00)00337-7

34. Laali, K. K.; Borodkin, G. I. J. Chem. Soc. Perkin Trans. 2 2002, 953-957. http://dx.doi.org/10.1039/b111725d

35. Reddy, S. A.; Laali, K. K. Tetrahedron Lett. 2015, 56, 5494-5499.

36. Hubbard, A.; Okazaki, T.; Laali, K. K. J. Org. Chem. 2008, 73, 316-319. http://dx.doi.org/10.1021/jo701937e

37. Laali, K. K.; Okazaki, T.; Bunge, S. J. Org. Chem., 2007, 72, 6758-6762. http://dx.doi.org/10.1021/jo0708801

38. Hubbard, A.; Okazaki, T.; Laali, K. K. Aust. J. Chem. 2007, 60, 923-927. http://dx.doi.org/10.1071/CH07261 
39. Pavlinac, J.; Laali, K. K.; Zupan, M.; Stavber, S. Aust. J. Chem. 2008, 61, 946-955. http://dx.doi.org/10.1071/CH08276

40. Vrazic, D.; Jereb, M.; Laali, K. K.; Stavber, S. Molecules 2013, 18, 74-96. http://dx.doi.org/10.3390/molecules18010074

41. Prebil, R.; Laali, K. K.; Stavber, S. Org. Lett. 2013, 15, 2108-2111. http://dx.doi.org/10.1021/o14001476

42. Kalkhambkar, R. G.; Waters, S. N.; Laali, K. K. Tetrahedron Lett. 2011, 52, 867-871. http://dx.doi.org/10.1016/j.tetlet.2010.12.028

43. Nandi, G. C.; Laali, K. K. Tetrahedron. Lett. 2013, 54, 2177-2179. http://dx.doi.org/10.1016/j.tetlet.2013.02.051

44. Jamalian, A.; Rathman, B.; Borosky, G. A.; Laali, K. K. Applied Catalysis A: General 2014, 486, 1-11. http://dx.doi.org/10.1016/j.apcata.2014.08.009

45. Aridoss, G.; Laali, K. K. Eur. J. Org. Chem. 2011, 2827-2835. http://dx.doi.org/10.1002/ejoc.201100128

46. Aridoss, G.; Laali, K. K. Eur. J. Org. Chem. 2011, 6343-6355. http://dx.doi.org/10.1002/ejoc.201100957

47. Aridoss, G.; Sarca, V. D.; Ponder, J. F.; Crowe, J.; Laali, K. K. Org. Biomol. Chem. 2011, 9, 2518-2529. http://dx.doi.org/10.1039/c0ob00872a

48. Aridoss, G.; Laali, K. K. Tetrahedron Lett. 2011, 52, 6859-6864. http://dx.doi.org/10.1016/j.tetlet.2011.10.021

49. Narayana Kumar, G. G. K. S.; Aridoss, G.; Laali, K. K. Tetrahedron Lett. 2012, 53, 30663069. http://dx.doi.org/10.1016/j.tetlet.2012.04.026

50. Narayana Kumar, G. G. K. S.; Laali, K. K. Tetrahedron Lett. 2013, 54, 965-969. http://dx.doi.org/10.1016/j.tetlet.2012.12.023

51. Narayana Kumar, G. G. K. S.; Laali, K. K. Org. Biomol. Chem. 2012, 10, 7347-7355. http://dx.doi.org/10.1039/c2ob26046h

52. Nandi, G. C.; Rathman, B.; Laali, K. K. Tetrahedron Lett. 2013, 54, 6258-6263. http://dx.doi.org/10.1016/j.tetlet.2013.09.028

53. Kalkhambkar, R. G.; Laali, K. K. Tetrahedron Lett. 2011, 52, 1733-1737. http://dx.doi.org/10.1016/j.tetlet.2011.02.021

54. Kalkhambkar, R. G.; Laali, K. K. Tetrahedron Lett. 2011, 52, 5525-5529. http://dx.doi.org/10.1016/j.tetlet.2011.08.077

55. Reddy, S.; Laali, K. K. Tetrahedron Lett. 2015, 56, 4807-4810. http://dx.doi.org/10.1016/j.tetlet.2015.06.067

56. Kalkhambkar, R. G.; Laali, K. K. Tetrahedron Lett. 2012, 53, 4212-4215. http://dx.doi.org/10.1016/j.tetlet.2012.05.155 


\section{Author's Biography}

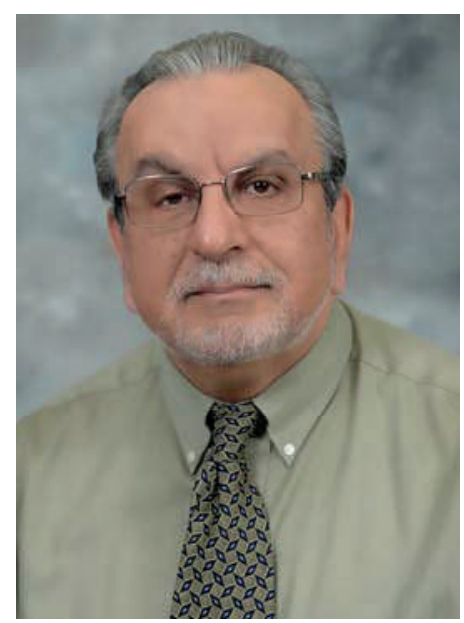

Kenneth Laali did his PhD work at the University of Manchester (with R. N. Haszeldine and B. L. Booth). A Postdoctoral stint at King's College London (with V. Gold) was followed by research appointments in Strasbourg (with J. Sommer), Amsterdam (with H. Cerfontain), and at ETH-Zurich (with H. Zollinger). In 1982 he joined George Olah's group at the University of Southern California, and in 1985 began his independent academic career at Kent State University where he went through the ranks and became Full Professor in 1996. In 2009 he moved to University of North Florida as Professor and Founding Chair of a New Chemistry Department, and in 2013 he was named UNF's $4^{\text {th }}$ Presidential Professor. He has authored over 200 publications and authored/coauthored 4 books and several book chapters. 